\title{
WAKAF TUNAI UNTUK PENGEMBANGAN \\ LEMBAGA PENDIDIKAN ISLAM DI INDONESIA
}

\author{
Anifah Purbowanti \\ Dani Muntaha \\ Universitas Negeri Semarang (UNNES) \\ e-mail:anifah133@gmail.com
}

\begin{abstract}
Education is the key to the progress of a nation. A nation whose quality of education is low, will be slumped and left behind from other nations. Conversely, a nation whose education is advanced, will excel from any nation. Indonesia is a country whose quality of education is very low. Economic crisis that plagued this country, increasingly difficult for the people of Indonesia to advance and improve the quality of education. The condition of poverty that menggurita which resulted in the worsening of education of the ummah, must be overcome immediately. This article discusses about the implementation of cash waqf (endowment) in Indonesia and its role in strengthening education. Cash waqf plays a significant role in some Islamic education institutionin providing material support. One example is Pondok Pesantren Gontor in East Java.
\end{abstract}

Keywords: Cash Waqf, Education, and Indonesia 


\section{Pendahuluhan}

Melihat sejarah umat Islam terdahulu ketika mengalami masa keemasan masalah pendidikan adalah masalah yang sangat diperhatikan. Hal ini terbukti dengan usaha pemerintah Islam membangun perpustakaan terbesar di Baghdad yang diberi nama "Baitul Hikmah" yang memiliki ribuan judul buku hasil dari pemikiran umat Islam sendiri. Kesemuanya itu tidak terlepas dari peran serta masyarakat Islam yang sangat antusias mengorbankan harta mereka demi kepentingan pendidikan (Chairul Hadi, 2009: 15). Bukanlah hal yang mustahil bahwa pendidikan sangat membutuhkan alokasi dana yang tinggi. Akan tetapi ketika pemerintahan Indonesia dihadapkan kepada masalah peningkatan kualitas pendidikan yang berkaitan dengan masalah dana, maka pemerintah cenderung berusaha untuk mengeksploitasi dana tersebut untuk kepentingan lainnya, dan menomorduakan masalah pendidikan.

Permasalahan pendidikan merupakan permasalahan sosial yang terjadi di Indonesia. Banyak sekolah-sekolah yang roboh, anak-anak yang putus sekolah, guru yang "nyambi" menjadi pemulung atau tukang ojek merupakan potret buram pendidikan di Indonesia. Mahalnya biaya sekolah dan buku-buku pelajaran menambah berat beban bagi orang tua dan perserta didik untuk memperoleh ilmu pengetahuan. Di Indonesia banyak sekolah yang roboh dan rusak, sedangkan banyak anak usia SD dan SMP putus sekolah dikarenakan ketidakmampuan mereka memenuhi biaya sekolah yang mahal. Semua permasalahan yang ada bermuara pada minimnya dana bagi pengembangan dunia pendidikan. Hasrat untuk mencetak manusia-manusia Indonesia yang unggul dan terdidik tersandung dengan minimnya dana yang dikucurkan bagi pendidikan. Walaupun pemerintah telah menaikkan anggaran pendidikan menjadi $20 \%$ dari keseluruhan APBN, akan tetapi realisasinya masih tersendat, karena faktor birokrasi dan korupsi serta pemotongan anggaran yang dilakukan 
oleh pembuat kebijakan sehingga anggaran yang diberikan tidak diterima sebagaimana yang dianggarkan.

Pendidikan menjadi kunci kemajuan sebuah bangsa. Bangsa yang kualitas pendidikannya rendah, akan terpuruk dan tertinggal dari bangsa-bangsa lain. Sebaliknya, bangsa yang pendidikannya maju, akan unggul dari bangsa manapun. Indonesia merupakan negara yang kualitas tingkat pendidikannya sangat rendah. Krisis ekonomi yang mendera negeri ini, semakin menyulitkan rakyat Indonesia untuk memajukan dan meningkatkan kualitas pendidikan. Kondisi kemiskinan yang menggurita yang mengakibatkan terpuruknya pendidikan umat, harus dientaskan dengan segera.

Pendidikan sudah tentu membutuhkan dana yang banyak untuk membiayai gaji guru, sarana dan prasarana, serta biaya para pelajar dalam masa pendidikan.Keterbatasan biaya pendidikan selalu menjadi sebab kegagalan dalam dunia pendidikan. Jadi sangat cocok jika wakaf menjadi salah satu sumber dana dalam memajukan pendidikan Islam, yang semakin tertinggal jika dibanding dengan pendidikan Barat. Salah satu upaya strategis untuk meningkatkan tingkat pendidikan umat Islam tersebut adalah melalui gerakan pemberdayaanwakaf produktif untuk pendidikan. Sesungguhnya Islam punya solusi yang ampuh untuk gerakan pemberdayaan umat melalui pendidikan. Salah satu solusinya adalah dengan mendayagunakan wakaf secara produktif. Disebut produktif, karena dana wakaf digunakan (diinvestasikan) untuk membiayai usaha-usaha produktif sedangkan bagi hasilnya diperuntukkan bagi kepentingan sosialekonomi umat, seperti beasiswa pendidikan.

Berdasarkan dengan masalah diatas, maka penulis menyusun karya tulis ilmiah ini ingin menjawab dua pokok masalah, yaitu: Pertama, Bagaimana pemberdayaan wakaf tunai untuk lembagapendidikan Islam di Indonesia. Kedua, Apa pengaruh pemberdayaan wakaf tunai terhadap perkembangan lembaga pendidikan Islam di Indonesia. 


\section{Pembahasan}

\section{Definisi wakaf}

Para fuqaha menggunakan entri "habs" dan "waqf" untuk membicarakan tentang wakaf. Untuk kata kerja digunakan kata "habasa atau ahbasa" dan "waqafa atau auqafa". Sedangkan untuk kata benda digunakan kata "waqf dan habs", yang bentuk jamaknya adalah auqaf,ahbas dan mahbus (Badan Wakaf Indonesia, 2015: 49).

Dalam al-Mu'jam al-Wasith tercantum kata "al-habs; alman'u wa al-imsak." Sedangkan habasa asy-syai' berarti: waqafa la yuba'u wa yuratsu (ditangguhkan, tidak boleh dijual dan tidak boleh diwarisi). Waqafa ad-dar berarti: habasaha fi sabilillah (menahannya untuk perjuangan fi sabilillah).

Kesimpulannya adalah bahwa al-habs dan al-waqf sama-sama mengandung makna al-imsak (menahan), alman'u(mencegah) danat-tamakkuts (diam/menetap). Maksudnya adalah menahan diri dari mengkonsumsi, menjual atau segala jenis tasaruf yang lain serta mempertahankan sesuatu dari semua perbuatan ini. Juga berarti menahan dan mencegah manfaat serta keuntungan dari seseorang atau tujuan yang tidak sejalan dengan tujuan perwakafannya(Badan Wakaf Indonesia, 2015: 51).

Sedangkan menurut istilah wakaf adalah menahan harta baik secara abadi maupun sementara, untuk dimanfaatkan langsung atau tidak langsung dan diambil manfaat hasilnya secara berulang-ulang, dijalan kebaikan, umum maupun khusus (Abdurrahman Kasdi, 2015: 14).

Definisi wakaf ini mengandung delapan hal: pertama, menahan harta agar tidak dikonsumsi atau digunakan secara pribadi. Kedua definisi wakaf ini mencakup harta, baik yang tetap dan tidak bisa bergerak seperti tanah dan bangunan, dan maupun berupa benda bergerak, seperti buku dan senjata, atau berupa barang seperti peralatan dan kendaraan, atau berupa uang seperti deposito dan pinjaman, atau bisa juga berupa manfaat yang 
mempunyai nilai uang seperti manfaat pengangkutan khusus orang sakit dan lanjut usia. Atau berupa manfaat dari harta benda tetap yang diwakafkan oleh penyewa. Ketiga mengandung pengertian melestarikan harta dan menjaga keutuhannya, sehingga memungkinkan untuk dimanfaatkan secara langsung atau diambil manfaat hasilnya secara berulang-ulang. Keempat definisi ini mengandung pengertian berulang-ulangnya manfaat dan kelanjutannya baik yang berlangsung lama, sebentar atau selamanya. Kelima definisi wakaf ini mencakup wakaf langsung yang mengahasilkan manfaat langsung dari harta atau benda yang diwakafkan. Keenam mencakup jalan kebaikan umum untuk keagamaan, sosial, dan lain sebagainya. Ketujuh mencakup pengertian wakaf menurut fikih dan Perundang-undangan, bahwa wakaf tidak terjadi kecuali dengan keinginan satu orang yaitu wakif saja. Kedelapan mencakup pentingnya penjagaan dan kemungkinan bisa diambil manfaatnya secara langsung atau dimanfaatkan hasilnya (Abdurrohman Kasdi, 2013: 14-6).

Dari delapan hal di atas dapat disimpulkan bahwa wakaf berfungsi sebagai upaya untuk membangun kesejahteraan umat. Menurut Muhammad Daud Ali seperti yang dikutip Uswatun Hasanah kesejahteraan secara harfiah bermakna keamanan dan kesejahteraan hidup termasuk kemakmuran, yaitu konsep yang menunjukkan keadaan, dimana setiap orang baik sebagai individu maupun sebagai anggota masyarakat dapat memenuhi kebutuhannya dengan mudah. Dengan demikian yang dimaksud dengan kesejahteraan adalah keadaan orang hidup aman dan tentram serta dapat memenuhi kebutuhan hidupnya (Farid Wadjidy dan Mursyid, 2007: 76).

\section{Wakaf uang}

Harta benda wakaf terdiri dari benda tidak bergerak dan benda bergerak. Wakaf benda tidak bergerak seperti tanah, dan bangunan, sedangkan wakaf benda bergerak adalah harta benda yang tidak bisa habis dikonsumsi, meliputi uang, logam mulia, 
surat berharga, kendaraan, hak atas kekayaan intelektual, dan hak sewa.

Wakaf uang (cash waqf) adalah wakaf yang dilakukan seseorang, kelompok orang, dan lembaga atau badan hukum dalam bentuk uang tunai (Direktorat Pemberdayaan Wakaf, 2006: 1). Uang pada awalnya hanya berfungsi sebagai alat tukar, sekarang uang sudah menjadi sesuatu yang dapat diwakafkan dan memberi manfaat yang sangat besar untuk kesejahteraan umat. Wakaf tunai adalah wakaf yang sifatnya produktif karena substansi atau wujudnya dipertahankan dan dikelola, sementara hasil atau manfaatnya digunakan sesuai dengan keinginan dari orang yang menyerahkan atau waqif. Uang pada awalnya hanya berfungsi sebagai alat tukar, sekarang uang sudah menjadi sesuatu yang diperjual belikan di berbagai kegiatan transaksi keuangan tersebut, sebenarnya akan menjadikan uang tersebut produktif.

Gerakan wakaf tunai (cash waqf) di zaman modern ini banyak mendapatkan perhatian dari para cendikiawan dan ulama. Di Indonesia para ekonomi syariah memandang wakaf tunai berpotensi menguatkan ekonomi umat. Urgensi dalam pengembangannya, maka lahirlah Undang-Undang Nomor 41 Tahun 2004 tentang wakaf uang dan Peraturan Pemerintah Nomor 42 Tahun 2006 tentang Pelaksanaan Undang-Undang Nomor 41 Tahun 2004.

Menurut Undang-undang Nomor 41 Tahun 2004 tentang wakaf, bahwa wakaf tunai tidak disebutkan secara langsung tentang pengertiannya, hanya pengertian wakaf secara umum. Yaitu perbuatan hukum wakif untuk memisahkan dan menyerahkan sebagian miliknya untuk dimanfaatkan selamanya atau jangka waktu tertentu sesuai dengan kepentingannya guna keperluan ibadah dan kesejahteraan umum menurut syariah. Namun, merujuk pada pasal 28 Undang-Undang Nomor 41 Tahun 2004 tentang wakaf disebutkan bahwa seorang wakif dapat mewakafkan benda bergerak berupa uang melalui lembaga 
keuangan syariah yang ditunjuk oleh Menteri (Direktorat Pemberdayaan Wakaf, 2006: 23-4).

Berdasarkan pengertian di atas dapat disimpulkan bahwa wakaf tunai adalah wakaf yang sifatnya produktif karena substansi atau wujudnya dipertahankan dan dikelola, sementara hasil atau manfaatnya digunakan sesuai dengan keinginan dari orang yang menyerahkan atau waqif.

\section{Landasan hukum wakaf}

Para ulama pada umumnya menggunakan dalil al-Quran dan hadis yang selama ini dipandang masyhur untuk dijadikan dasar hukum wakaf, meskipun dalil-dalil yang dimaksud tidak secara tekstual menyebut kata wakaf, namun secara kontekstual menggunakan pemaknaan wakaf. Di dalam al-Quran banyak ayat yang menganjurkan agar seseorang muslim membelanjakan sebagian harta dengan menggunakan kata "infaq", sedangkan dalam hadis sering ditemui kata "habs", dan kedua istilah tersebut para ulama menyamakan dengan kata "wakaf".

Disebutkan dalam Ensiklopedia Islam bahwa secara khusus tidak ditemukan nash al-Qur'an maupun hadis yang secara tegas menyebutkan dasar hukum yang melegitimasi dianjurkannya wakaf. Tetapi secara umum banyak ditemukan ayat-ayat alQur'an dan hadis yang menganjurkan orang yang beriman mau menyisihkan sebagian dari kelebihan hartanya digunakan untuk kegiatan yang produktif bagi masyarakat. Di antara nash al-Quran dan hadis yang dapat dijadikan sumber hukum wakaf ialah:

1. Surat Ali Imran ayat 92 yang artinya: "Kamu sekali-kali tidak sampai kepada kebajikan (yang sempurna), sebelum kamu menafkahkan sehahagian harta yang kamu cintai. dan apa saja yang kamu nafkahkan Maka Sesungguhnya Allah mengetahuinya."(QS. Ali Imran: 92)

2. Surat Al-Baqarah ayat 262 yang artinya:"Orang-orang yang menafkahkan hartanya di jalan Allah, kemudian mereka tidak 
mengiringi apa yang dinafkahkannya itu dengan menyebutnyebut pemberiannya dan dengan tidak menyakiti (perasaan si penerima), mereka memperoleh pahala di sisi Tuhan mereka. tidak ada kekhawatiran terhadap mereka dan tidak (pula) mereka bersedih hati." (QS. Al-Baqarah: 262)

3. Hadist yang artinya: "Diriwayatkan dari Abu Hurairah, Rasulullah SAW bersabda: apabila manusia meninggal, terputuslah pahala amal perbuatannya, kecuali tiga hal: sedekah jariah, ilmu yang bermanfaat, dan anak yang shaleh yang mendoakannya".

Imam Nawawi menyatakan bahwa hadis ini merupakan dalil wakaf dan besarnya pahala wakaf, menurutnya, yang dimaksud dengan sedekah jariah adalah wakaf.

"Diriwayatkan Ibnu Umar berkata, "Umar radhiyallaahu'anhu memperoleh bagian tanah di Khaibar, lalu menghadap Nabi SAW, untuk meminta petunjuk dalam mengurusnya. Ia berkata, "Wahai Rasulullah, aku memperoleh sebidang tanah di Khaibar, yang menurutku, aku belum pernah memperoleh tanah yang lebih baik dari padanya." Beliau bersabda, "jika engkau mau, wakafkanlah pohonya dan sedekahkanlah hasil (buah)nya." Ibnu Umar berkata, "lalu Umar mewakafkannya dengan syarat pohonnya tidak boleh dijual, diwariskan, dan diberikan. Hasilnya disedekahkan kepada kaum fakir, kaum kerabat, para hamba sahaya, orang yang berada dijalan Allah, musafir yang kehabisan bekal, dan tamu. Pengelolanya boleh memakannya dengan sepantasnya dan memberi makan sahabat yang tidak berharta. (Muttafaq'alaih dan lafazhnya menurut riwayat muslim) (Ibnu Hajar al-Asqalani, 2013: 400). 


\section{Wakaf uang sebagai sumber dana abadi bagi pemberdayaan pendidikan umat}

Manfaat wakaf secara umum adalah mengekalkan manfaat benda wakaf sesuai dengan tujuan wakaf, yaitu melembagakan manfaat benda wakaf untuk selama lamanya guna kepentingan ibadat dan keperluan umum lainnya sesuai dengan ajaran Islam. Fungsi atau manfaat ini juga tentunya dapat diperluas dari praktek wakaf tunai diantara lain manfaat wakaf tunai diantaranya adalah:

1. Seseorang yang memiliki dana terbatas sudah bisa mulai memberikan dana wakafnya tanpa harus menunggu menjadi tuan tanah atau orang kaya terlebih dahulu.

2. Melalui wakaf uang, aset-aset wakaf yang berupa tanah-tanah kosong bisa mulai dimanfaatkan dengan pembangunan gedung atau sarana lain yang lebih produktif untuk kepentingan umat.

3. Dana wakaf tunai juga bisa membantu sebagian lembagalembaga pendidikan islam.

4. Umat islam dapat lebih mandiri dalam mengembangkan dunia pendidikan tanpa harus terlalu tergantung pada anggaran pendidikan Negara yang memang semakin lama semakin terbatas.

Fakta sejarah menunjukkan bahwa banyak lembaga yang bisa bertahan dengan lembaga yang bisa bertahan dengan memanfaatkan dana wakaf, dan bahkan memberikan konstribusi yang signifikan. Beberapa lembaga pendidikan Islam terkemuka mampu bertahan bahkan berabad-abad lamanya. Bahkan mereka telah memberikan beasiswa kepada ribuan mahasiswa dari berbagai penjuru dunia Islam. Sebagiai contoh adalah Universitas Al-Azhar Mesir, Universitas Zaituniyah Tunis, Universitas Nizhamiyah di Baghdad dan ribuan madaris Imam Lisesi di Turki. Pada lembaga-lembaga tersebut bukanlah lembaga pendidikan yang profit oriented tapi lebih merupakan lembaga pendidikan 
yang social oriented. Jawabannya adalah karena mereka telah berhasil dalam mengelola wakaf tunai untuk mengelola dan operasional lembaga pendidikan (Nurodin Usman, tt: 14).

Untuk kasus Indonesia, wakaf tunai telah terbukti membantu tugas Negara dalam meningkatkan kesejahteraan masyarakat yang mungkin tidak tertangani oleh Negara.hal ini karena terbatasnya dana yang disediakan Negara serta krisis ekonomi yang berkepanjangan, terutama dikalangan umat islam. Dalam bidang pendidikan kita melihat lebih jauh kiprah seperti Pondok Pesantren Modern Gontor, Pesantren as-Salam, Yayasan Wakaf UII, Universitas Sultan Agung, UMI Makasar, UISU Medan, serta lembaha wakaf dibawah naungan NU, Muhammadiyah al- Washilah.

Betapa besar sumbangsih yang telah mereka berikan kepada dunia pendidikan bangsa kita. Sebagian dari lembagalembaga ini masih bersahaja bertahan dengan kesederhanaan mereka namun sebagian yang lain telah tumbuh menjadi lembaga pendidikan yang maju, berkembang pesat serta memiliki daya saing yang tinggi. Mereka bertahan tanpa memperoleh perhatian dari pemerintah tapi secara mandiri mengelola dana wakaf umat yang diamanahkan kepada mereka.

\section{Peran wakaf untuk pendidikan dari masa ke masa}

Wakaf memiliki peranan dalam meningkatkan peradaban umat Islam, lewat lembaga-lembaga wakaf yang berfungsi sebagai tempat penyebaran ilmu dan budaya, dan memberikan ruang bagi ulama, para ahli fikih dan budayawan untuk mengembangkan keilmuan dan keahliannya. Sejak awal Islam, umat Islam telah memberikan perhatianya terhadap pembangunan masjid. Masjid bukan saja menjadi tempat untuk beribadah, akan tetapi menjadi juga pusat da'wah Islam, tempat penyiaran, pengajaran risalah Islam, bahkan tepat untuk membahas permasalahanpermasalahan politik dan sosial. Sebagian besar masjid didirikan dengan status wakaf. Masjid wakaf pertama kali berdiri adalah 
masjid Quba', yang didirikan oleh Rasulullah SAW saat pertama kali menginjakkan kakinya di Madinah, kemudian Masjid Nabawi yang didirikan tahun pertama Hijriah, kemudian bermunculan masjid-masjid wakaf pada masa Khulafă’ al-Rasyidīn, Bani Umayyah dan Bani al-'Abbās.

Masjid-masjid yang terkenal yang menjadi qiblat bagi para ulama dan penuntut ilmu seperti masjid Nabawi dan masjid al-Harām di Makkah, masjid Kuffah tahun 14 H, masjid Basrah tahun $17 \mathrm{H}$, masjid Umawy di Damaskus tahun 19H, Jami' Amr ibn al-'Ash di Mesir tahun 21 H, Jāmi' Ibn Thulūn tahun $258 \mathrm{H}$, dan Jāmi al-Azhar tahun 359 H. Masjid-masjid tersebut selain digunakan untuk beribadah, juga mengadakan aktivitas kajian agama dan bahasa Arab, bahkan juga mengadakan kajian ilmuilmu modern ketika itu seperti kedokteran, falak, hisab dan lain sebagainya (Ahmad Furqon, 2010: 41).

Bahkan beberapa universitas yang terkenal hingga sekarang, berasal dari masjid seperti universitas al-Azhar Kairo, Universitas al-Zaitunah Tunis, dan Universitas al-Qurawiyyin Maroko. Ibnu Bāthūtah menggambarkan akitivitas ilmu yang terjadi di masjid pada masa itu, ia mengatakan:"Masjid-masjid mengadakan halaqah-halaqah yang menggajarkan bermacammacam ilmu pengetahuan. Para ahli hadis membacakan hadis diatas bangku tinggi, dan membaca al-Qur'an dengan bacaan yang bagus setiap pagi dan sore. Beberapa kelompok guru mentalqinkan bacaan al-Qur'an kepada anak-anak kecil, mereka tidak menulis al-Qur'an di papan tulis karena takut merusak citra al-Qur'an. Pengajar ilmu menulis, mengajarkan cara menulis syair, sehingga anak-anak setelah belajar membaca, mereka belajar menulis.

Lembaga pendidikan berbasis wakaf yang juga memiliki peran dalam kemajuan peradaban umat Islam adalah madrasah. Berbeda dengan lembaga pendidikan sebelumnya yang ciri khasnya berdampingan dengan masjid, maka madrasah terpisah dengan masjid. Madrasah melakukan proses pendidikan dengan 
cara yang lebih formal, memiliki tingkatan-tingkatan dan batas waktu pendidikan. Proses pendidikan dibiayai dengan dana wakaf sehingga siswa-siswa belajar dengan gratis. Biaya operasional madrasah seperti menggaji guru dan alat-alat pengajaran dibiayai dengan hasil wakaf.

Madrasah wakaf yang terkenal dalam sejarah Islam adalah madrasah al-Nizhāmiyah di Baghdad yang didirikan oleh Bani Saljuk Turki tahun 459H. Tujuan pendirian madrasah ini menurut Nizhām al-Mulk untuk mencetak pemuda-pemuda calon pemimpin bangsa yang memiliki ilmu atas dasar akidah ahl al-Sunnah. Madrasah ini mengajarkan fikih empat madzhab disamping ilmu-ilmu umum dan kedokteran (Ahmad Furqon, 2010: 43).

Al-Jāmi' al-Azhar merupakan masjid sekaligus lembaga pendidikan yang didirikan oleh Jauhar al-Shaqily (panglima pasukan Mu'iz li Dinillah al-Fathimy) pada tahun 359H. Nama alAzhar diambil dari Fatimah al-Zahrā'. Pada tahun 365H, Hakim agung Ali ibn Nu'mān al-Qairawany mengadakan halaqah yang merupakan halaqah ilmu pertama yang diadakan di al-Jāmi' al-Azhar (Anan, 1354H:41\&66). Selanjutnya al-Jami' al-Azhar mengalami perkembangan dalam penyebaran ilmu pengetahuan agama. Lewat perubahan kekuasaan, al-Jāmi; al-Azhar tidak hanya mengajarkan fiqih mazhab Syi'ah akan tetapi juga fikih mazhab Imam-Imam yang empat. Telah banyak ulama-ulama terkenal yang belajar maupun mengajar di al-Jāmi' al-Azhar. Diantara ulama yang merupakan alumni al-Azhar adalah Ibnu Khaldun, sedangkan ulama-ulama terkenal yang pernah mengajar di sana, diantaranya adalah: al-Suyuthi, al-Maqrizy, al-Qalqasyandi, alHāfizh Ibn Hajar al-' Asqalany, Subhu al-A'sy, dan al-Maqry, ahli hadis terkenal ketika itu (Ahmad Furqon, 2010: 39).

Menjadi semakin jelas peranan wakaf dalam meningkatkan peradaban, karena wakaf memberikan dana untuk meningkatkan aktivitas ilmiah, meningkatkan budaya, memberantas buta huruf, dan membangun peradaban Islam yang humanis. 


\section{Pemberdayaan wakaf uang untuk lembaga pendidikan Islam di Indonesia}

Salah satu bentuk wakaf produktif yang sangat populer dan banyak dikembangkan saat ini adalah cash wakaf (wakaf uang tunai). Wakaf tunai adalah wakaf yang dilakukan seseorang, kelompok orang dan lembaga atau badan hukum dalam betuk uang. Hukum wakaf tunai telah menjadi perhatian para fuqaha' (Juris Islam). Beberapa sumber telah menyebutkan bahwa wakaf tunai telah dipraktikan oleh masyarakat yang menganut mazhab Hanafi (Direktorat Pemberdayaan Wakaf, 2006: 3).Cara melakukan wakaf tunai (mewakafkan uang), menurut mazhab Hanafi ialah dengan cara mudharabah atau mubadha'ah. Sedangkan keuntungannya disedekahkan kepada pihak yang berhak menerima wakaf (Direktorat Pemberdayaan Wakaf, 2006: 5).

Wakaf uang menjanjikan kemanfaatan yang lebih baik yang dapat diperoleh dari sumber-sumber wakaf selain pemanfaatan hasil pengelolaan wakaf, wakaf tunai juga dapat memperluas jangkauan pemberi wakaf dan peningkatan produktivitas harta wakaf. Pengelolaan dana wakaf tunai sebagai alat untuk investasi menjadi menarik, karena faedah atau keuntungan atas investasi tersebut dalam bentuk keuntungan yang akan dapat dinikmati oleh masyarakat dimana saja (baik local, regional maupun international). Hal ini dimungkinkan karena faedah atas investasi tersebut berupa uang tunai (cash) yang dapat dialihkan kemana pun. Disisi investasi atas dana wakaf tersebut dapat dilakukan dimana saja tanpa batas Negara. Hal inilah yang diharapkan mampu meningkatkan keharmonisan antara masyarakat kaya dengan masyarakat miskin (Suhrawardi K Lubis, 2010: 110).

Wakaf dalam bidang pendidikan telah menjadi bagian penting dari sejarah perwakafan Islam. Keberadaan wakaf telah membantu penyediaan fasilitas-fasilitas publik di bidang pendidikan, seperti madrasah, pondok-pondok pesantren, ma'had. Langkah yang harus dilakukan untuk memberdayakan dana wakaf tunai untuk pendidikan diprioritaskan kepada 
pembangunan (Pesantren, Madrasah dan Perguruan Tinggi Islam, Lembaga riset untuk masyarakat dan Perpustakaan) dan Pemberdayaan dan Pengembangan (Kurikulum, Sumber Daya Manusia, Proyek-proyek riset teknologi tepat guna) (Direktorat Pemberdayaan Wakaf, 2007: 76-8).

Pondok pesantren Gontor di jawa Timur merupakan salah satu contoh lembaga yang dibiayai dari dana wakaf. Pondok Modern Darussalam Gontor (PMDG) ditopang oleh sekitar 320 hektar lahan wakaf, 212 hektar diantaranya adalah sawah produktif. Disini pondok Gontor memperoleh hasil panen senilai Rp 726 juta tiap dua musim panen. Selain dari sawah padi, pondok modern Gontor juga memperoleh pendapatan dari kebun cengkeh dan kegiatan niaga lain di lingkungannya meski relatif lebih kecil. Dengan dukungan dana wakaf ini, pondok Gontor mampu menyediakan jasa pendidikan bermutu bagi sekitar 35 ribu siswa dengan biaya yang relatif murah. Sebagian besar benda wakaf gontor dikelola secara produktif dengan usaha pertanian, perkebunan, percetakan, retail, apotik, wartel, penggilingan padi, toserba dan lain-lain yang hasilnya untuk pengelolaan dan pengembangan pendidikan yang terdiri dari Kuliyatul Muallimin Al-Islamiyah (KMI), Institut Pendidikan Darussalam (IPD), Kuliyatul Muallimat Al-Islamiyah (KMI Putri) dan pusat latihan manajemen dan pengembangan masyarakat (PLMPM), serta untuk kepentingan masyarakat sekitar (Farid Wadjidy dan Mursyid, 2007: 125).

Untuk melaksanakan tugas pengelolaan aset dan harta benda wakaf dibentuklah YPPWPM (Yayasan Pemeliharaan dan Perluasan Wakaf Pondok Modern). Yayasan atau lembaga ini ditunjuk oleh Badan wakaf untuk mengelola aset dan tanahtanah wakaf dan mengusahakan pengembangannya. YPPWPM selanjutnya membentuk bagian-bagian. Antara lain, bagian pemeliharaan dan pertanian, yang bertugas memelihara tanah dan lahan-lahan pertanian serta mengelola hasilnya. Satu bagian lain berkenaan dengan perluasan dan perawatan. Bagian ini 
menangani usaha-usaha perluasan wakaf dan mengurus status hukum dan administrasi pertanahannya. Bagian ketiga berkenaan dengan pergedungan dan peralatan yang bertugas memelihara dan menambah sarana pergedungan dan peralatan untuk kepentingan pendidikan dan pengajaran.

Pemberdayaan harta wakaf yang dimiliki oleh PMDG awalnya berupa tanah, kemudian dimanfaatkan dengan mendirikan pertokoan, percetakan, retail dan lain-lain, pendanaan dari pendirian tempat usaha itu berasal dari SPP atau Infaq para santri yang belajar disana, pembayaran infaq tersebut dijadikan sebagai wakaf tunai untuk mendanai tempat usaha yang didirikan di atas tanah wakaf milik PMDG. Infaq wali santri yang ditujukan untuk pondok dianggap sebagai wakaf, dengan alasan dana tersebut tidak secara langsung digunakan untuk operasional pondok, tetapi menjadi aset pondok yang selanjutnya diberdayakan melalui unit-unit usaha milik pondok. Sumber wakaf yang diperoleh dan infaq wali santri jumlahnya cukup besar (Rozalinda, 2015: 316). Hasil dari pemberdayaann wakaf tunai tersebut digunakan untuk pemenuhan kebutuhan para santri selama belajar di PMDG, pembangunan sarana dan prasarana belajar serta pemberian beasiswa bagi para santri untuk melakukan study yang lebih tinggi lagi.

Pemberdayaan wakaf sektor pertanian lebih dikembangkan dan semula hanya ditanami padi dan tebu sekarang diolah secara intensif dengan menanam tanaman keras yang produktif sehingga memberikan manfaat lebih optimal. Sebagian lahan disekitar Gontor 1, Gontor 2, dan ISID ditanami sayur-sayuran, seperti bayam, kangkung dan sawi dan sebagian lagi digunkan untuk mengembangkan budidaya jamur, tanaman pete, rambutan, buah naga dan pohon jati. Di Pondok Gontor 3 Darul Ma'rifah Kediri mengembangkan sektor pertanian dan perkebunan dengan budidaya jamur, melon, tomat, cabe keriting, jagung dan rempahrempah. Sementara itu, di Jambi sekarang sedang dicoba untuk membuka kebun kelapa sawit seluas 300 ha, dengan harapan 
kedepan akan dibuka cabang Pondok Modern Darussalam Gontor di wilayah ini (Rozalinda, 2015: 325-6).

Pemberdayaan wakaf untuk sektor usaha dan perdagangan mendirikan Percetakan Darussalam (Darussalam Press and Printing) dengan tujuan untuk mencetak buku-buku wajib di KMI. Setiap siswa baik lama maupun baru membutuhkan buku wajib dan anjuran antara 10-15 buah. Apabila masing-masing siswa membutuhkan buku rata-rata sebanyak 12 buah, maka sebanyak 13.900 orang membutuhkan buku tidak kurang dari 166.000 exemplar (Rozalinda, 2015: 327). Percetakan tersebut bukan hanya untuk memenuhi kebutuhan para siswa siswi KMI di Gontor pusat dan cabang, namun juga disediakan untuk pondok pesantren alumni yang berjumlah ratusan diseluruh Indonesia. Pimpinan pondok juga mendirikan toko buku La Tansa di Pusat Kota Ponorogo yang digunakan untuk memenuhi pemasaran, sehingga masyarakat umum dapat mendapat buku yang diterbitkan oleh pesantren, hal ini akan menjadikan pemasukan di Pesantren menjadi lebih banyak.

Pada tahun 2003 Badan Wakaf mendirikan pabrik roti La Tansa Bakery dengan tujuan untuk memenuhi warung-warung pondok. Pabrik roti memiliki kemampuan produksi sebanyak 1.400-1.600 perhari dikemas dalam lima macam produk yaitu roti keju, roti meisis, isi daging, pisang dan abon. Hasil produksi roti La Tansa di distribusikan malalui warung-warung pondok dan dipasarkan ke warung-warung masyarakat sekitra pondok. Produk roti La Tansa beredar di pondok-pondok cabang seperti Pondok Gontor 2, Pondok Gontor Putri 1, Pondok Gontor Putri 2 dan Pondok Gontor putri 3 dikabupaten Ngawi (Rozalinda, 2015: 329).

Masih banyak lagi pemberdayaan wakaf yang dilakukan oleh Pondok Modern Darussalam Gontor yang hasilnya dimanfaatkan untuk meningkatkan dan mensejahterakan pendidikan di pesantren Gontor. Hasil dari pemberdayaan wakaf produktif difokuskan untuk membangun sarana dan prasarana 
pendidikan, digunakan untuk memenuhi kebutuhan santri selama belajar di pesantren, memberikan beasiswa untuk dapat belajar ke jenjang yang lebih tinggi dan digunakan untuk memggaji para guru dan dosen yang mengajar disana.

\section{Pengaruh pemberdayaan wakaf uang terhadap perkembangan lembaga pendidikan Islam di Indonesia}

Wakaf dan pendidikan berputar dalam satu lingkaran, masing-masing dipengaruhi oleh yang sebelumnya dan mempengaruhi yang sesudahnya. Ketika banyak orang yang berwakaf untuk pendidikan, maka makmurlah lembagalembaga pendidikan dan lembaga riset yang selanjutnya menghasilkan banyak orang-orang pandai yang nantinya juga akan mengeluarkan wakaf. Sebaliknya, dizaman kemunduran tidak banyak orang yang mengeluarkan wakaf untuk pendidikan, yang menyebabkan kemunduran lembaga-lembaga pendidikan dan lembaga riset, selanjutnya membawa kurangnya orang-orang pandai dikalangan islam sendiri yang mampu mengeluarkan wakaf. Maka dari itu, jalinan antara wakaf dan pendidikan sangat diperlukan untuk mendukung mata rantai kebangkitan dunia islam (Abdurrohman Kasdi, 2015: 166).

Adanya pemberdayaan wakafyang difokuskan untuk peningkatan kualitas pendidikan yang dapat menciptakan sumber daya manusia yang lebih baik dan berkualitas. Hal tersebut dapat dibuktikan banyaknya santri dan guru yang mendapat beasiswa untuk meneruskan pendidikan ke jenjang yang lebih tinggi baik di dalam maupun di luar negeri. Semakin banyaknya sumber daya manusia yang berkualitas disuatu Negara maka akan menjadikan Negara tersebut menjadi lebih maju, dan dengan majunya Negara maka tingkat kemiskinan dapat diatasi dengan mudah, sehingga rakyat akan menjadi makmur dan sejahtera. Teori tersebut sesuai dengan tujuan wakaf produktif yang bertujuan untuk menjadikan masyarakat menjadi lebih sejahtera. 
Contoh lembaga yang berhasil memberdayakan wakaf produktif untuk menigkatkan dan mengembangkan pendidikan adalah Universitas Al-Azhar Asy-Syarif di Cairo Mesir, di AlAzhar telah terbukti dengan memberdayakan wakaf produktif universitas tersebut menjadi sangat maju terutama dibidang pendidikan. Pemanfaatan hasil wakaf Al-Azhar yakni dengan memfasilitasi sarjana dan mahasiswa melalui sarana dan prasarana yang memadai, mereka bisa melakukan berbagai kegiatan riset (penelitian) dan menyelesaikan studi mereka secara gratis. Sangat banyak program yang didanai dari hasil wakaf seperti penulisan buku, penerjemahan dan kegiatan-kegiatan ilmiah dalam berbagai bidang. Wakaf bukan hanya mendukung pengembangan ilmu pengetahuan, tetapi juga menyediakan berbagai fasilitas yang diperlukan mahasiswa maupun masyarakat (Abdurrohman Kasdi, 2015: 167).

Pengaruh pemberdayaan wakaf terhadap pendidikan jelas terlihat pada sarana dan prasarana yang ada pada sebuah lembaga pendidikan yang lebih lengkap dan memadai untuk kegiatan pembelajaran. Maju tidaknya sebuah lembaga pendidikan dapat dilihat dari sarana dan prasarana yang disediakan oleh lembaga pendidikan. Saat sarana dan prasarana telah terpenuhi dengan baik maka kegiatan belajar untuk menciptakan SDM yang berkualitas juga akan berjalan dengan baik.

\section{Simpulan}

Pemberdayaan wakaf tunai secara produktif adalah digunakan untuk modal usaha seperti menanami tanah persawahan dan perkebunan yang kemudian membuka pasar tempat penjualan hasil panen, membuka pabrik roti yang kemudian juga membuka toko roti yang digunakan untuk menjual roti yang dihasilkan dari pabrik roti tersebut,membuka toko printing dan percetakan untuk mencetak buku yang dibutuhkan para siswa yang dijual di toko milik lembaga pendidkan tersebut. Hasil dari penjualan barang yang dihasilkan tersebut digunakan 
untuk membangun sarana dan prasarana lembaga pendidikan, memenuhi kebutuhan para siswa, agar dapat belajar dengan biaya yang murah, memberikan beasiswa untuk para siswa dan guru yang berprestasi untuk belajar ke jenjang yang lebih tinggi dan digunakan untuk membayar gaji para guru.

Pemberdayaan wakaf menjadi produktif memiliki pengaruh yang sangat besar kepada perkembangan lembaga pendidikan islam di Indonesia. Salah satunya dapat dilihat dengan semakin lengkapnya fasilitas yang disediakan oleh lembaga pendidikan, kualitas pembelajaran yang diberikan semakin baik karena banyak para pendidikan yang diberikan beasiswa untuk dapat belajar lebih tinggi lagi dengan dibiayai dengan harta wakaf yang diproduktifkan sehingga dapat mengajar para siswa dengan lebih baik lagi. Selain itu lembaga pendidikan juga dapat memberikan fasilitas yang lengkap kepada para siswa dengan biaya pendidikan yang murah, sehingga memberikan kemudahan kepada seuruh golongan untuk dapat mendapatkan pendidikan yang layak, sehingga dapat menciptakan sumber daya manusia yang berkualitas.

\section{Daftar Pustaka}

Abdurrohman Kasdi, Fikih Wakaf: Dari Wakaf Klasik Hingga Wakaf Produktif, Idea Press, Yogyakarta, 2013

Abdurrohman Kasdi, Wakaf Produktif Untuk Pendidikan: Model Pengelolaan Wakaf Produktif Al-Azhar Asy-SyarifCairo Mesir, CV. Idea Sejahtera, Yogyakarta, 2015

Ahmad Furqon, Wakaf Sebagai Solusi Permasalahan Permasalahan Dunia Pendidikan Di Indonesia, Jurnal Hukum Islam (JHI) Volume 10, Nomor 1, Juni 2012

Chairul Hadi, Peluang Wakaf Produktifuntuk Pembiayaan Pendidikan Islam, Turats, Vol. 5, No. 1, Juni 2009 
Departemen Agama RI, Pedoman Pengelolan WakafTunai, Direktorat Pemberdayaan Wakaf Direktorat Jenderal Bimbingan Masyarakat Islam, Jakarta, 2006

Departemen Agama RI, Strategi Pengembangan Wakaf Tunai Di Indonesia, Direktorat Pemberdayaan Wakaf dan Direktorat Jenderal Bimbingan Masyarakat Islam Departemen Agama RI, Jakarta, 2007

Farid Wadjdy dan Mursyid, Wakaf Dan Kesejahteraan Umat: Filantropi Islam Yang Hampir Terlupakan, Pustaka Pelajar, Jogjakarta, 2007

Ibnu Hajar al-Asqalani, Bulughul Maram Dan Dalil Dalil Hukum, Gema Insani, Jakarta, 2013

Nurodin Usman, Wakaf Produktif Sebagai Alternatif Sumber Dana Abadi Bagi Lembaga Pendidikan Islam, Artikel Universitas Muhammadiyah Magelang, $\mathrm{tt}$

Rozalinda, Managemen Wakaf Produktif, PT. Raja Grafindo Persada, Jakarta, 2015

Suhrawadi K Lubis, Wakaf Dan Pemberdayaan Umat, Sinar Grafika, Jakarta, 2010

Wakaf Islam (Sejarah, Pengelolaan Dan Pengembangannya), Badan Wakaf Indonesia, Jakarta, 2015 